\title{
Merawat Kerukunan di Desa Cikawungading, Kecamatan Cipatujah, Kabupaten Tasikmalaya, Jawa Barat
}

\author{
Deni Miharja \\ UIN Sunan Gunung Djati - Bandung \\ denimiharja@uinsgd.ac.id \\ Wawan Hernawan \\ UIN Sunan Gunung Djati - Bandung \\ wawanhernawan@uinsgd.ac.id
}

\begin{abstract}
There is a relationship among religion, social and environmental conditions as a place of settlement of a society. This is a hypothesis of caring for harmony in Cikawungading Village. Through this hypothesis, the social environment has a significant influence on the form of the relationship. The process of social transformation is possible so that needed to maintain harmony, because in this village there were attacks and burning on 36 houses, 2 churches and a wood processing factory, with a total of 181 refugees. The focus of this study is to find out the characteristics of the Cikawungading Village community's diversity and the efforts that must be carried out by government agencies, institutions under the Ministry of Religion, and Universities in providing assistance and understanding about the importance of harmonious living in the conditions of pluralistic and multi-religious communities. To answer this problem, researchers used Quintan Wiktorowicz's social movement theory with a multidisciplinary approaches. The results showed, firstly, the community in Cikawungading village have now lived in harmony with each other. They have accustomed to mutual understanding in worship, giving each other help, and not disturbing each other. Secondly, the concern of government agencies, institutions under the Ministry of Religion, and Higher Education is expected to be present in their midst. The expected form of attendance is the training, especially in the momentum of religious holidays and activities to increase community income.
\end{abstract}


[Hubungan antara agama dengan kondisi sosial dan lingkungan sebagai tempat bermukimnya suatu masyarakat merupakan hipotesis dari merawat kerukunan di Desa Cikawungading. Melalui hipotesis ini, penelitian lingkungan sosial memiliki pengaruh signifikan terhadap bentuk hubungan tersebut. Proses transformasi sosial dimungkinkan terjadi sehingga perlu merawat kerukunan, karena di desa ini pada tahun 2001 telah terjadi penyerangan dan pembakaran terhadap 36 rumah penduduk, 2 gereja, dan sebuah pabrik pengolahan kayu, dengan jumlah pengungsi secara keseluruhan mencapai 181 jiwa. Fokus dari kajian ini adalah ingin mengetahui karakteristik keberagamaan masyarakat Desa Cikawungading dan upaya yang harus dilakukan instansi pemerintah, lembaga-lembaga di bawah Kementerian Agama, maupun Perguruan Tinggi dalam melakukan pendampingan dan pemberian pemahaman tentang pentingnya hidup rukun dalam kondisi masyarakat yang majemuk dan multi religi. Untuk menjawab masalah tersebut, peneliti menggunakan teori gerakan sosial dari Quintan Wiktorowicz dengan pendekatan multidisipliner. Hasil penelitian menunjukkan, pertama, masyarakat di Desa Cikawungading kini telah hidup rukun satu dengan lainnya. Mereka sudah terbiasa saling pengertian dalam ibadah, saling memberi bantuan, serta tidak saling mengganggu. Kedua, kepedulian instansi pemerintah, lembaga-lembaga di bawah Kementerian Agama, maupun Perguruan Tinggi sangat diharapkan untuk hadir di tengahtengah mereka. Bentuk kehadiran yang diharapkan, terutama dalam momentum kegiatan Peringatan Hari Besar Keagamaan dan kegiatan peningkatan pendapatan masyarakat adalah melalui pelatihan.

Keywords: dialogue, integration, conflict, reconciliation, tolerance.

\section{Pendahuluan}

Senin, 17 September 2001 sekira pukul 16.30 WIB., masyarakat Desa Cikawungading, tepatnya di Kampung Kalaksanan dikejutkan oleh penyerangan sekelompok massa yang dilanjutkan dengan pembakaran 
terhadap 36 rumah penduduk, 2 buah gereja, dan sebuah pabrik pengolahan kayu. ${ }^{1}$ Menurut Mailing List BPK Gerakan Pemuda GPIB Forum Diskusi Antar Pemuda GPIB disebutkan lebih rinci, bahwa sekitar 300-an warga telah membakar Gereja Kristen Pasundan, Gereja Advent, 23 rumah warga Kristen, lima warung, satu pabrik pengolahan kayu, satu buah truck, dan satu mesin diesel. ${ }^{2}$ Bukan hanya itu, massa juga menjarah dan merusak sejumlah rumah lainnya. Akibatnya, terdapat 39 Kepala Keluarga (KK) yang mengungsi ke Kantor Kecamatan Cipatujah dan $23 \mathrm{KK}$ melarikan diri ke hutan dengan jumlah keseluruhan pengungsi mencapai 181 jiwa. $^{3}$ Tak pelak, peristiwa itu telah menoreh daftar yang ikut mengubah wajah hubungan antar agama di Indonesia. Bahkan kondisi itu semakin mengkhawatirkan dengan munculnya serangkaian peristiwa serupa pada tahun-tahun selanjutnya, hingga muncul stigma, Jawa Barat merupakan provinsi paling intoleran di Indonesia. ${ }^{4}$ Dalam situasi dan kondisi yang serba kurang menguntungkan itu dipandang perlu setiap individu, instansi pemerintah, lembagalembaga di bawah Kementerian Agama, atau akademisi untuk menelusuri, mengkaji, dan menemukan trace (jejak) guna diperoleh solusi dalam menggamit rekonsiliasi dan integrasi, intern, antar, dan antara pemeluk agama dengan pemerintah.

Terkait dengan stigma, Jawa Barat merupakan provinsi paling intoleran di Indonesia, jauh sebelum adanya peristiwa dan survei tersebut, sebetulnya pola laku (pattern of behavior) dan pola budaya (pattern

\footnotetext{
1 Upiek S. dan Y. Tomi Aryanto, "Diduga Akibat Persaingan Usaha Kerusuhan di Tasikmalaya, 36 Rumah dan 2 Gereja Hancur", dalam http://www.oocities.org/baguala67/tempo190901.-htm?20185/ diakses 07 Oktober 2016.

${ }^{2}$ Komunitas Member Miling List GP 2000, "Dua Gereja dan Puluhan Rumah Warga Kristen Dibakar", dalam http:// www.communityzero.com/gpgpib/diakses 05 Oktober 2018.

${ }^{3}$ Ibid.

${ }^{4}$ Lihat, Setara Institute, Report Summary Tolerant City Index 2015 Jakarta: Setara Institute, 2015), 4. Lihat pula, The Wahid Institute, Laporan Tabunan Kemerdekaan Beragama/Berkeyakinan (KBB) di Indonesia: “Utang” Warisan Tak Kunjung Terlunasi (Jakarta: The Wahid Institute, 2015), 33. Bandingkan dengan, Komnas HAM, Laporan Tabunan Kebebasan Beragama dan Berkeyakinan 2016 (Jakarta: Komnas HAM, 2016), 21.
} 
of culture) orang Jawa Barat telah mempunyai prinsip siger tengah, nonmilitan, non-ekstrim, dan non-revolusioner. ${ }^{5}$ Orang Jawa Barat lebih dikenal puitis, romantis, melodius, dan mistis. ${ }^{6}$ Mereka lebih menghendaki sebuah tatanan masyarakat yang memperlakukan warganya dengan harga diri dan rasa hormat. ${ }^{7}$ Bagi orang Jawa Barat, tidak ada ruang untuk intimidasi atau apa pun sejenis itu. Orang Jawa Barat lebih menantikan kehidupan beretika, karena mereka menyadari bahwa melalui hidup beretika akan mampu melahirkan transformasi sosial ke arah masyarakat yang menjunjung tinggi kebajikan. Meskipun demikian, masih dalam pola laku dan pola budaya orang Jawa Barat, tidak mengajarkan untuk menjadi "orang" dalam pengertian menerima atau melaksanakan sebagian dari norma apalagi nilai agama yang dianutnya, tetapi bertindak dengan tidak berlebihan dalam perkataan dan perbuatan. ${ }^{8}$

Karena itu, dengan adanya kasus-kasus intoleransi yang berujung pada stigma, Jawa Barat merupakan provinsi paling intoleran di Indonesia, memunculkan rasa ingin tahu peneliti tentang karakteristik keberagamaan masyarakat, khususnya di Cikawungading dan upaya yang harus dilakukan dalam melakukan pendampingan serta pemberian pemahaman tentang pentingnya hidup rukun dalam kondisi masyarakat yang majemuk dan multi religi. Untuk itu, meskipun agak belakangan, yaitu baru dimulai pada medio akhir 2016, seiring LP2M UIN Sunan Gunung Djati Bandung mengeluarkan program Pengabdian Masyarakat Berbasis Riset, peneliti merasa terpanggil untuk melakukan kegiatan pengabdian masyarakat di Desa tersebut. Pemilihan lokasi itu, setelah sebelumnya mendapatkan ekspose dan pemetaan' yang dilakukan oleh Forum Kerukunan Umat Beragama (FKUB) Kabupaten Tasikmalaya.

\footnotetext{
5 Tjetje H. Padmadinata, "Panggung Karakter Elite Sunda", dalam HU Pikiran Rakyat, 5 April 1997, 5.

${ }^{6}$ Ibid., 7.

${ }^{7}$ Ibid., 9.

${ }^{8}$ Ibid., 11.

${ }^{9}$ Utawi Jaya Kusumah, Wawancara, Tasikmalaya 26 April 2016.
} 
Penelitian ini tentu tidak akan mengungkap seluruh aspeknya tentang Desa Cikawungading, terutama pra-peristiwa, peristiwa, dan akibat-akibat yang ditimbulkan pada peristiwa 17 September 2001. Tetapi, lebih difokuskan pada isu "merawat kerukunan" di sebuah desa multi religi. Isu merawat kerukunan dijadikan objek kajian untuk mengetahui posisi individu, instansi pemerintah, lembaga-lembaga di bawah Kementerian Agama, dan Perguruan Tinggi di tengah kecenderungan menguatnya pandangan intoleran, disharmoni, dan seterusnya. Gagasan merawat kerukunan dapat ditelusuri tidak hanya melalui keberpihakan program pemerintah, tetapi juga pada upaya dialog yang dibangun di antara unsur-unsur itu. Dialog kehidupan terjadi, ketika beberapa pihak memiliki kesadaran bersama, untuk bertemu, bertatap muka, dan berbicara secara bersama-sama tentang kehidupan mereka bersama. ${ }^{10}$ Melalui pengabdian masyarakat berbasis riset ini diharapkan mampu menjembatani hubungan yang kurang harmonis pada intern, antar, dan antara umat beragama dengan pemerintah, ${ }^{11}$ sehingga praktik intoleransi dapat diminimalkan di Jawa Barat.

\section{Teori Gerakan Sosial Quintan Wiktorowicz}

Pengabdian masyarakat berbasis riset ini menggunakan teori gerakan sosial dari Quintan Wiktorowicz dengan pendekatan multidisipliner. Menurut Quintan, terdapat tiga konsep utama dalam teori gerakan sosial yang memainkan peran sangat penting dalam menentukan keberhasilan aksi-aksi kolektif. Pertama, struktur kesempatan politik (political opportunity structure). Kedua, struktur mobilisasi (mobilizing structures). Ketiga, pembingkaian aksi (framing). ${ }^{12}$ Konsep struktur kesempatan politik

\footnotetext{
10 Rachel Iwamony \& Tri Astuti Relmasira "Rekonsiliasi sebagai Proses Bersama Menyembuhkan Luka Sejarah Islam-Kristen di Kota Ambon", Jurnal Religio, Vol. 7, No 2, 2017, 4-5.

11 Ahsanul Khalikin dan Fathuri, Toleransi Beragama di Daerah Rawan Konflik (Jakarta: Puslitbang Kehidupan Keagamaan Badan Litbang dan Diklat Kemenag RI, 2016), 5657.

12 Quintan Wiktorowicz, (ed.), Islamic Activism: A Social Movement Theory Approach (Indiana: Indiana University Press, 2004), 2-6.
} 
menjelaskan, bahwa munculnya gerakan sosial sering kali diawali oleh perubahan-perubahan signifikan yang terjadi dalam struktur politik. Untuk itu, meredupnya gerakan itu juga biasanya berhubungan dengan pergeseran-pergeseran yang terjadi di dalamnya. Dapat dikatakan, struktur kesempatan politik memiliki pengaruh kepada mempercepat atau pun mengakhiri aksi kolektif. ${ }^{13}$ Namun demikian, struktur kesempatan politik saja tidak cukup untuk mendorong terjadinya aksi kolektif. Ia harus ditopang oleh struktur mobilisasi yang biasanya berakar pada jaringan-jaringan sosial yang sudah terbentuk sebelumnya.

Melalui jaringan itu, massa dan simpatisan direkrut dan dimobilisasi. Keberadaan jaringan rekrutmen menjadi penentu dalam proses pelibatan individu, karena mobilisasi tidak berlangsung dalam ruang kosong. ${ }^{14}$ Untuk memobilisasi massa, aktor-aktor gerakan sosial perlu membingkai aksi-aksi yang mereka rencanakan dengan slogan-slogan dan bahasa yang mudah dipahami dan sekaligus dapat menggerakkan sentimen mereka. Di sinilah arti penting framing sebagai seni mengkomunikasikan pesan untuk menggerakkan audience dan memompa dukungan serta partisipasi. ${ }^{15}$ Ideologi dan tidak jarang teologi, sebagai sistem kepercayaan, ide, nilai, dan makna, biasanya bekerja untuk mendukung efektivitas framing ini. Teori gerakan sosial memberikan keuntungan bagi upaya memahami berbagai gejala multidisipliner.

Sementara metode yang dipakai adalah metode penelitian sosial keagamaan melalui teknik dokumentasi, observasi, dan wawancara. ${ }^{16}$ Dalam dokumentasi sumber, peneliti melakukan penelusuran melalui searching internet, berkunjung ke FKUB Kabupaten Tasikmalaya, perpustakaan UIN Sunan Gunung Djati Bandung, Kantor Desa

\footnotetext{
${ }^{13}$ Noorhaidi Hasan, "Book Review: Islam Politik, Teori Gerakan Sosial, dan Pencarian Model Pengkajian Islam Baru Lintas-Disiplin”, Al-Jami'ah Journal of Islamic Studies, Vol. 44, No. 1, (2006), 245.

14 Ibid., 247.

${ }^{15}$ Ibid., 250.

${ }^{16}$ Wawan Hernawan, Seabad Persatuan Ummat Islam (Bandung: PUI dan YMSI Cabang Jawa Barat, 2014), 28.
} 
Cikawungading, dan ke Kampung Kalaksanan. Dengan demikian, penelitian ini banyak dilakukan di Tasikmalaya dan Bandung. Dalam teknik dokumentasi dilakukan langsung oleh peneliti. Hal itu dilakukan berdasarkan pertimbangan, bahwa: pertama, peneliti sebagai alat peka dan dapat bereaksi terhadap segala stimulus dari sumber atau lingkungan yang diperkirakan bermakna atau tidak bagi penelitian. Kedua, peneliti sebagai alat dapat menyesuaikan diri terhadap semua aspek keadaan dan dapat mengumpulkan aneka ragam data sekaligus. Ketiga, tiap situasi merupakan keseluruhan. Peneliti sebagai instrument dapat memahami situasi dalam segala seluk-beluknya. Keempat, peneliti sebagai instrument dapat segera menganalisis data yang diperoleh sekaligus menentukan arah pengamatan. ${ }^{17}$

Teknik pengumpulan data dalam penelitian ini dilakukan melalui observasi dan interview (wawancara). Observasi dilakukan untuk mengumpulkan informasi yang berkenaan dengan perilaku keagamaan, materi gerakan, interaksi intern, interaksi antara kelompok keagamaan setempat, dan pemerintah. Dalam setiap observasi, peneliti berupaya menggali cultural meaning dari setiap objek yang diamati. Hal tersebut dapat berhasil apabila peneliti mampu mengaitkan antara informasi yang diterima dengan konteks situasi dan kondisi yang mengitari objek penelitian. Karena makna dari sesuatu tindakan dapat diperoleh dari kaitan antara informasi dengan konteksnya. $^{18}$ Adapun interview (wawancara) dilakukan untuk menggali informasi mengenai pikiran atau gerakan, sehingga diketahui lebih mendalam bagaimana responden memandang pasca penyerangan pada 17 September 2001 di Kampung Kalaksanan Desa Cikawungading dari segi perspektifnya, atau dengan kata lain untuk mencari informasi emik. Informasi tersebut kemudian diinterpretasi oleh peneliti, sehingga melahirkan etik pandangan peneliti

${ }^{17}$ Ibid., 28-29.

${ }^{18}$ Dadang Kahmad, "Kajian tentang Pengambilan Keputusan untuk menjadi Pengikut Tarekat Qadiriyah Naqsabandiyab; Studi Kasus di Kecamatan Ujungberung Bandung”, Tesis S 2 tidak dipublikasikan, (Bandung: Universitas Padjadjaran, 1993), 73. 
tentang data. ${ }^{19}$ Sedangkan objek penelitian ini adalah menganalisis faktorfaktor dominan yang dilakukan individu, instansi pemerintah, lembagalembaga di bawah Kementerian Agama, atau akademisi, setelah terjadinya praktik penyerangan dan pembakaran di Desa Cikawungading.

\section{Memahami Keragaman}

Dalam credo (tata keyakinan) semua pemeluk agama-agama, diakui bahwa agama merupakan sumber inspirasi bagi terciptanya keadilan dalam kehidupan sosial umat manusia. Alur sejarah kehidupan berbangsa dan bernegara dalam Negara Kesatuan Republik Indonesia (NKRI) yang sangat panjang telah membentuk agama-agama menampakkan dirinya secara heterogen yang terkadang kontra produktif dengan fungsi dan misi yang include di dalam agama itu sendiri. Kuat dugaan, itulah yang kemudian melahirkan kehidupan keagamaan masyarakat Indonesia menjadi beragam. ${ }^{20}$

Terkait dengan realitas keragaman kehidupan keagamaan masyarakat Indonesia, Evans Pritchard menyatakan: "Tidak ada masyarakat yang dapat hidup tanpa sesuatu seperti sains dan sesuatu seperti agama. Semua kebudayaan selalu membutuhkan konsepsi pemikiran dari sains dan construct of heart agama". ${ }^{21}$ Seseorang tanpa komitmen agama tidak akan berhasil dalam usaha menyusun teori sains, karena ia akan segera jatuh kepada pemahaman reduksionisme. 22 Pritchard perlu didukung, karena manusia sampai kapan dan di mana pun memang tidak pernah lepas dari agama atau sesuatu yang menyerupainya (pseudo-agama). Jika ada manusia yang mengakui tidak menganut agama formal tertentu, hal itu bukan jaminan bahwa ia lepas dari keberagamaan sama sekali.

\footnotetext{
${ }^{19}$ Ibid., 74.

${ }^{20}$ Hendrianto Atan, "Kita Butuh Agama yang Peka Tuntutan Zaman", dalam Nurcholis Madjid et al., Islam Universal (Yogyakarta: Pustaka Pelajar, 2007), v.

${ }^{21}$ Lihat, E.E. Evans Pritchard, "'Construct of Heart' Masyarakat", dalam Daniel L. Pals, Seven Theories of Religion, Alih Bahasa Ali Noer Zaman, Peny Ruslani, (Yogyakarta: Qalam, 2001), 378.

${ }^{22}$ Ibid., 380.
} 
Dalam konteks ini, "kami" sependapat dengan konfirmasi yang dilakukan Mircea Eliade, bahwa umat manusia sepanjang waktu terusmenerus bekerja untuk menyatakan kembali persepsi mereka tentang yang sakral melalui cara-cara awal. Mereka menciptakan mitos-mitos baru, menemukan simbol-simbol yang segar, serta menyusunnya kembali ke dalam sistem yang berbeda atau bahkan lebih luas. ${ }^{23}$ Melalui pernyataannya itu, Eliade seolah ingin menegaskan, bahwa manusia tidak mungkin dapat dilepaskan dari agama sama sekali, karena di dalam dirinya telah terdapat dorongan alamiah untuk membayangkan adanya yang sakeral agar hidupnya dapat lebih bermakna.

Agama dalam konteks pemahaman Eliade tersebut, diduga bukan seperti yang dibayangkan kebanyakan orang sebagai agama formal. Dalam hal ini, agama yang tidak mungkin dapat dilepaskan dari manusia itu adalah segala jenis agama, baik yang formal maupun tidak, asalkan ia menduduki posisi sebagai sistem budaya yang hidup di dalam masyarakat. Agama sebagai sistem budaya merupakan sebuah sistem simbol yang berperan membangun suasana hati dan motivasi yang kuat, persuasif, dan tahan lama di dalam diri manusia. Melalui sistem simbol itu, agama merumuskan konsepsi tatanan kehidupan yang umum. Ia membungkus konsepsi itu dengan suatu aura faktualitas, sehingga suasana hati dan motivasi tampak menjadi realitas yang unik". ${ }^{24}$ Agama dalam kedudukan sebagai sistem budaya inilah yang selalu membayangi dan mewarnai hidup dan kehidupan manusia di mana pun mereka berada.

Agama sebagai sistem budaya tentu perlu dibedakan dengan agama sebagai doktrin yang tertulis di dalam Kitab Suci. Agama sebagai sistem budaya telah mengalami interelasi-dialektis dengan kebudayaan dan masyarakatnya. Jika agama telah menjadi bagian dari kebudayaan, maka ia secara sosial adalah konteks makna yang dipahami bersama. Agama

\footnotetext{
${ }^{23}$ Mircea Eliade, "Realitas yang Sakral", dalam Daniel L. Pals, Seven Theories of Religion, terjemahan Ali Noer Zaman, disunting Ruslani, (Yogyakarta: Qalam, 2001), 300.

${ }^{24}$ Clifford Geertz, "Agama sebagai Sistem Budaya", dalam Daniel L. Pals, Seven Theories of Religion, terjemahan Ali Noer Zaman, disunting Ruslani, (Yogyakarta: Qalam, 2001), 412-417.
} 
terdiri atas struktur arti yang mapan yang para penganutnya melakukan hal-hal semacam itu sebagai konspirasi yang jelas untuk bergabung di dalamnya. Para penganutnya, jika merasakan penghinaan, maka mereka akan menjawabnya secara bersama-sama. ${ }^{25}$

Terkait dengan hal itu Berger ${ }^{26}$ mengungkapkan, eksistensi manusia pada awal dan akhirnya merupakan aktivitas yang mengeksternalisasi. ${ }^{27}$ Selama proses eksternalisasi tersebut, ia mencurahkan makna ke dalam realitas. Sementara agama dalam kaitan itu merupakan fakta sosial. Ia sebagai jangkauan terjauh dari eksternalisasi diri manusia, dari peresapan makna-maknanya sendiri ke dalam realitas. Melalui konsep tersebut kemudian dapat dijelaskan bagaimana hubungan satu agama dengan agama-agama dan atau kepercayaan lain — bahkan dengan kebudayaan masyarakat tertentu seperti Jawa Barat - dapat terbangun sebagai suatu sistem kultural. Secara komprehensif, Berger menyatakan lebih lanjut, hubungan agama (keyakinan) dengan masyarakat dan lingkungannya dapat dilihat sebagai proses dialektik yang terdiri atas tiga momentum, yaitu: eksternalisasi, objektivikasi, dan internalisasi. Pertama, momentum eksternalisasi terjadi ketika seorang manusia yang hidup dalam masyarakat mencurahkan eksistensi dirinya secara terus menerus ke dalam dunia baik dalam aktivitas fisik maupun mental. Kedua, momentum objektivikasi, yakni ketika kecenderungan manusia melakukan eksternalisasi berdialektika dengan fakta-fakta yang melingkunginya. Ketiga, momentum internalisasi, yaitu ketika mulai terbentuk idiom-idiom budaya yang kemudian disandangnya. Internalisasi terjadi ketika

25 Ibid., 409.

26 Peter L. Berger adalah tokoh yang mencetuskan teori konstruksi sosial bersama rekannya Thomas Luckman pada 1990. Teori itu kemudian ditulis dan dipublikasikan dalam bukunya berjudul, The Sosial Construction of Reality: A Treatise in the Sociology of Knowledge.

${ }^{27}$ Dalam konsepsi Berger, istilah eksternalisasi dimaksudkan sebagai salah satu dari 3 (tiga) momentum dari proses dialektika fundamental masyarakat. Sementara 2 (dua) momentum lainnya merupakan objektivikasi dan internalisasi. Istilah eksternalisasi sendiri dimaksudkan sebagai suatu pencurahan kedirian manusia secara terus-menerus ke dalam dunia, baik dalam aktivitas fisik maupun mentalnya. Lihat, Peter L. Berger, The Sacred Canopy, terjemahan Hartono, (Jakarta: LP3ES, 1990), 34-35. 
lingkungan yang melingkupinya terlalu kuat mendominasi dirinya, sehingga ia harus menerima pengaruh lingkungannya agar tetap dapat berinteraksi dengan mereka. Hingga di sini dapat dipahami, melalui eksternalisasi manusia menciptakan masyarakat dan kebudayaannya; melalui objektivikasi, masyarakat dan kebudayaan menjadi realitas unik yang berhadap-hadapan dengan manusia, dan melalui internalisasi, masyarakat dan kebudayaan mempengaruhi individualitas manusia. ${ }^{28}$ Itulah keragaman yang beragam, itulah kita "manusia".

Keragaman merupakan fakta yang ada di dunia ini, sehingga keberadaannya tidak bisa dihindari. Hal terpenting, bahwa setiap kehidupan akan mengalami proses transformasi sosial. Soemardjan mendefinisikan transformasi sosial adalah semua perubahan yang terjadi pada lembaga-lembaga kemasyarakatan dalam suatu masyarakat di mana perubahan tersebut mempengaruhi sistem sosialnya yang mencakup nilai, sikap, dan pola tingkah laku di antara kelompok-kelompok masyarakat. ${ }^{29}$ Masyarakat di seluruh dunia saat ini sedang ditransformasikan secara dramatis oleh globalisasi. ${ }^{30}$

\section{Desa Cikawungading dalam Angka}

Lokasi pengabdian masyarakat berbasis riset ini bertempat di Desa Cikawungading Kecamatan Cipatujah Kabupaten Tasikmalaya. Desa Cikawungading mempunyai luas wilayah $2.638 \mathrm{~km}^{2}$. Desa ini memiliki potensi sumber daya alam yang besar, baik di bidang pertanian, pertambangan, perikanan, dan pariwisata. Berdasarkan letak geografis berbatasan langsung dengan Samudera Indonesia. Wilayah ini dialiri oleh tiga sungai, yaitu: sungai Ci Langla, Ci Cadas (anak Sungai Ci Langla),

\footnotetext{
28 Ibid., 37.

29 Dakir "Pengelolaan Budaya Inklusif Berbasis Nilai Belom Bahadat pada Huma Betang dan Transformasi Sosial Masyarakat Dayak Kalimantan Tengah”. Jurnal Religio, Vol. 7, No 2, 2017, 36.

30 Salehudin, Ahmad \& Ichwan, Moch Nur. "Revitalisasi Identitas Diri Komunitas Masjid Saka Tunggal Banyumas, Masjid Raya Al Fatah Ambon,dan Masjid Agung Jami’ Singaraja Bali dalam Perubahan Budaya Global” Jurnal Religio, Vol. 7, No 2, 2017, 55.
} 
dan sungai Cikawungading. Wilayah desa Cikawungading mempunyai batas-batas, sebagai berikut: ${ }^{31}$

- Sebelah Barat: Desa Sindangkerta dan Desa Kertasari,

- Sebelah Timur: Desa Cidadap (Kecamatan Karangnunggal),

- Sebelah Utara: Desa Sarimukti (Kecamatan Karangnunggal),

- Sebelah Selatan: Samudera Hindia.

Desa Cikawungading memiliki beberapa dusun di dalamnya diantaranya adalah dusun Cikawungading dengan luas wilayah $290 \mathrm{Ha}$, dusun Sukasari dengan luas $310 \mathrm{Ha}$, dusun Pantilaksana dengan luas 276 $\mathrm{Ha}$, dusun Sukasirna dengan luas $320 \mathrm{Ha}$, dusun Mekarjaya dengan luas $298 \mathrm{Ha}$, dusun Sindangsari dengan luas $315 \mathrm{Ha}$, dusun Buniayu dengan luas $263 \mathrm{Ha}$, dusun Kalaksanan dengan luas $286 \mathrm{Ha}$, dan dusun Pamayangsari dengan luas $280 \mathrm{Ha}$, sehingga total secara keseluruhan luas desa Cikawungading adalah $2.638 \mathrm{Ha}$.

Desa Cikawungading termasuk pada zona rangkaian pegunungan yang mempunyai batuan induk. Batuan-batuan yang terdapat di wilayah Cikawungading adalah jenis batuan kapur, karena wilayah ini berada dekat dengan laut sehingga sebagian besar batuan yang ada di wilayah ini adalah jenis batuan kapur karena terbentuk sebagai akibat kompaksi dari material batuan beku, batuan sedimen, dan batuan malihan dengan ukuran butir beragam. Karena pembentukan tersebut diakibatkan oleh angin, air, dan es, kemudian disebut juga batuan sedimen mekanik. ${ }^{32}$

Desa Cikawungading memiliki jumlah penduduk 6.855 orang dengan 2.189 Kepala Keluarga (KK). Mayoritas penduduk Desa Cikawungading adalah sebagai petani, tetapi ada pula yang berprofesi sebagai Pegawai Negeri Sipil (PNS), nelayan, buruh dan lain-lain. Penduduk di Desa Cikawungading merupakan salah satu desa di Kabupaten Tasikmalaya yang multi-religi, yaitu: Islam, Katolik, dan Protestan. Masyarakat yang beragama Islam sejumlah 6.636 orang.

31 Profil Desa Cikawungading Kecamatan Cipatujah Kabupaten Tasikmalaya Tahun 2016.

32 Ibid., 3. 
Sedangkan yang menganut Katolik dan Protestan sejumlah 219 orang. Penduduk yang beragama Katolik dan Protestan seluruhnya bersuku dan berbahasa Jawa yang berasal dari Jawa Tengah. ${ }^{33}$

Komposisi penduduk menurut umur dan jenis kelamin sangat penting untuk diketahui. Komposisi ini akan mencerminkan kemampuan suatu daerah dilihat dari sumber daya manusianya. Dengan komposisi penduduk tersebut dapat diketahui sex ratio, struktur penduduknya, kelompok usia produktif, usia belum produktif, dan usia tidak produktif, sebagaimana tabel berikut:

\section{Komposisi Penduduk Berdasarkan Usia dan Jenis Kelamin}

\begin{tabular}{ccccc} 
No. & $\begin{array}{c}\text { Kelompok } \\
\text { Usia }\end{array}$ & \multicolumn{2}{c}{ Jenis Kelamin } & Jumlah \\
& $0-4$ & $\mathrm{~L}$ & $\mathrm{P}$ & \\
1 & $0-4$ & 457 & 464 & 922 \\
2 & $05-12$ & 350 & 317 & 667 \\
3 & $13-15$ & 320 & 246 & 566 \\
4 & $16-19$ & 232 & 214 & 446 \\
5 & $20-24$ & 204 & 196 & 400 \\
6 & $25-29$ & 250 & 264 & 514 \\
7 & $30-34$ & 242 & 274 & 516 \\
8 & $35-39$ & 249 & 296 & 545 \\
9 & $40-44$ & 185 & 174 & 359 \\
10 & $45-49$ & 191 & 173 & 364 \\
11 & $50-54$ & 205 & 200 & 405 \\
12 & $55-59$ & 186 & 187 & 373 \\
13 & $60-64$ & 192 & 204 & 396 \\
14 & $65+$ & 175 & 214 & 389 \\
& Jumlah & $\mathbf{3 4 3 8}$ & $\mathbf{3 4 1 7}$ & $\mathbf{6 8 5 5}$
\end{tabular}

Sumber: Data Monografi Desa Cikawnngading 2015

${ }^{33}$ Ibid., 7. 
Tingkat pendidikan masyarakat Desa Cikawungading masih tergolong sangat rendah. Pada umumnya masyarakat hanya menyekolahkan anaknya sampai tingkat SD. Kendala utama adalah faktor ekonomi. Mayoritas penduduk memiliki mata pencaharian sebagai petani dan banyak yang masih beranggapan, bahwa sekolah itu mahal. Karena itu, mereka lebih mendorong anak-anaknya untuk bekerja, baik membantu pekerjaan orang tuanya, maupun kerja di luar kota. Komposisi penduduk Desa Cikawungading berdasarkan tingkat pendidikan, sebagai berikut:

\section{Komposisi Penduduk Berdasarkan Pendidikan}

$\begin{array}{clcc}\text { No. } & \text { Tingkat Pendidikan } & \text { Jumlah } & \begin{array}{c}\text { Persentase } \\ \mathbf{( \% )}\end{array} \\ 1 & \text { Belum Sekolah } & 957 & 13,7 \\ 2 & \text { Belum Tamat SD } & 1811 & 26,4 \\ 3 & \text { Tamat SD } & 2572 & 37,3 \\ 4 & \text { Tamat SLTP } & 1032 & 15,6 \\ 5 & \text { Tamat SLTA } & 435 & 6,3 \\ 6 & \text { Tamat Perguruan Tinggi } & \mathbf{4 8} & 0,70 \\ & & \mathbf{6 8 5 5} & \mathbf{1 0 0}\end{array}$

Sumber : Data Monografi Desa Cikawnngading 2015

Pada umumnya masyarakat Desa Cikawungading memanfaatkan lahan pengangonan untuk dijadikan lahan pertanian. Tanaman kelapa sangat cocok di wilayah ini, karena merupakan daerah dataran rendah. Tanaman kelapa tersebut banyak dimanfaatkan untuk diambil air niranya sebagai bahan baku pembuatan gula kelapa, masyarakatnya yang berprofesi sebagai buruh tani dan petani sebesar 68\%. Selain itu, mereka ada yang bekerja sebagai nelayan sebanyak 19\%. Namun demikian, ada yang berprofesi sebagai Pegawai Negeri Sipil (PNS) sebanyak 1\%, dan 
peternak, seperti: ayam, domba, kambing, dan sapi sebanyak 1\%, pedagang sebesar $10 \%$.

Sementara keyakinan keagamaan masyarakat Desa Cikawungading dapat dikatakan multi-religi. Meskipun mayoritas jumlah penduduknya adalah Muslim dengan jumlah 6.624 jiwa atau 96,63\%, namun terdapat umat Kristiani, terutama masyarakat di Kampung Kalaksanan yang jumlahnya sebesar 231 jiwa atau 3,37\%. Umat Kristiani yang tinggal di Desa Cikawungading terdiri dari Katolik dan Protestan. Karena itu, di desa ini terdapat dua Gereja, yaitu: Gereja Kristen Pasundan (GKP) Kalaksanan (Katolik), dan Gereja Advent Kalaksanan (Protestan). Melihat inisial tempat yang menunjuk kepada tempat kedua Gereja, yaitu Kalaksanan, kedua Gereja tersebut berada di Kampung Kalaksanan. Kedua Gereja itu pun mempunyai susunan pengurus/organisasi dan jemaat, sebagai berikut: Pertama, Gereja Kristen Pasundan (GKP) Kalaksanan, berdiri pada 1934 dengan jumlah jemaat 213 jiwa (68 KK). GKP Kalaksanan digembalakan oleh Ketua Umum: Pdt. Arni Selvi Mence Bitjara, dengan Ketua: Bapak Supardi, Sekretaris: Ibu Wigati, dan Bendahara: Ibu Lina. Susunan organisasi lainnya dalam Struktur Organisasi GKP Kalaksanan, masing-masing: Bidang Peribadahan \& Pembinaan, Bidang Keesaan \& Kesaksian, Bidang Penelitian \& Pengembangan, Bidang Sarana \& Dana, Koord. Komisi Pelayanan Anak, Koord. Komisi Pelayanan Pemuda Remaja, Koord Komisi Pelayanan Perempuan, Koord. Komisi Pelayanan Bapak, Koord. Komisi Pelayanan Lansia, Koord. Komisi Diakonia, dan Koord. Komisi Dana Usaha. ${ }^{34}$

Data jemaat GKP Kalaksanan Desa Cikawungading, terdiri dari 66 laki-laki dan 80 perempuan dewasa, 56 anak-anak/remaja, dan 11 orang murid Taman Kanak-kanak. Jemaat GKP Kalaksanan dewasa berdasarkan tempat kelahiran: Cianjur (1 orang), Sumedang (1 orang), Bandung (1 orang), Medan (2 orang), Salatiga (4 orang), 7 orang tidak mengisi asal kelahiran, dan sisanya kelahiran Tasikmalaya. Jemaat GKP Kalaksanan dewasa berdasarkan tempat domisili terakhir: Banjar (1

\footnotetext{
${ }^{34}$ Data Monografi Desa Cikawungading 2015.
} 
orang), Tangerang (1 orang), Palembang (1 orang), Bangka (2 orang), Sindangkerta (3 orang), Bandung (4 orang), Karang (5 orang), tidak mengisi domisili terakhir (3 orang), dan sisanya tinggal di Kampung Kalaksanan. Sementara remaja dan anak-anak yang belum menikah mengikuti dan tinggal bersama orang tua mereka.

Kedua, Gereja Advent Kalaksanan, berdiri 12 Agustus 1974, dengan jumlah jemaat 18 jiwa (8 KK). Gereja Advent Kalaksanan dipimpin oleh Ketua: Bapak Saino, Sekretaris: Bapak Teguh, dan Bendahara: Ibu Neni. Ukuran Gereja: 6 × $9 \mathrm{M}^{2}$, asal tanah: Ibu Jazmi Katijah. Adapun data jemaat Gereja Advent Kalaksanan, terdiri dari 10 orang laki-laki dewasa dan 8 orang perempuan dewasa. Suatu yang disesalkan, data tentang tempat kelahiran jemaat Gereja Advent Kalaksanan, dalam Data Monografi Desa Cikawungading 2015, tidak dirinci sebagaimana jemaat GKP Kalaksanan. Namun demikian disebutkan, seluruh jemaat Gereja Advent Kalaksanan sekarang berdomisili di Kampung Kalaksanan. ${ }^{35}$

Dinamika keberagamaan masyarakat Desa Cikawungading ketika kami mengadakan pengabdian masyarakat berbasis riset sebenarnya berjalan cukup baik. Kehidupan keberagamaannya pun penuh dengan kedamaian, toleran, dan harmonis. Namun demikian, seiring perjalanan waktu terdapat hal yang mengagetkan umat Islam di sana, yaitu masalah pindah keyakinan (konversi agama). Di Desa Cikawungading yang mayoritas Muslim dan santri, karena keberadaan Gereja dan penganutnya, terjadilah komunikasi yang intens di antara penganut berbeda agama itu. Hasilnya, itulah yang diduga kuat menjadi pangkal persoalan, yaitu ada beberapa umat Islam yang tergiur dengan ajakan Gereja, sehingga terjadi konversi agama dari Islam ke Kristen. ${ }^{36}$

Namun demikian, hal menarik selanjutnya adalah konversi agama mereka ternyata tidak berlangsung lama. Mereka yang semula menyatakan pindah agama dan memeluk agama Kristen, kemudian konversi kembali menjadi pemeluk agama Islam. Perilaku konversi agama di

35 Ibid., 6.

${ }^{36}$ Edeng Z.A., Wawancara, Tasikmalaya 26 Oktober 2016. 
desa ini merupakan hal yang biasa. Bahkan dalam satu keluarga pun ada yang berbeda agama. Lagi-lagi hal itu pun menjadi hal yang biasa. ${ }^{37}$ Para mualaf di Desa Cikawungading hingga tahun 2016 berjumlah 57 orang. Mereka terdiri dari 25 laki-laki dan 32 perempuan yang tersebar di kampung Sukasirna (1 orang), Cikawungading (1 orang), Buniayu (1 orang), Pamayangsari (3 orang), Pantilaksana (6 orang), dan sisanya tinggal di Kampung Kalaksanan. ${ }^{38}$ Itulah yang kemudian kami sebut, Desa Cikawungading sebagai desa multi religi dan desa kerukunan.

\section{Merawat Kerukunan}

Menyadari dinamika agama dan keberagamaan masyarakat Desa Cikawungading yang dapat dikatakan multi-religi, sesuai amanah pemerintah, Forum Kerukunan Antar Umat Beragama (FKUB) ${ }^{39}$ Kabupaten Tasikmalaya hadir dan sering menyambangi desa itu. Di antara program yang ditawarkan, pertama: gerakan pemuda pelopor hidup rukun. ${ }^{40}$ Tujuan kegiatan tersebut, sebagai ajang anjangsana guna penyadaran peran generasi muda dalam mewujudkan gerakan hidup rukun serta membangun komitmen bersama, toleran, dan bersedia saling tolong-menolong antar sesama. Kedua, kegiatan yang dilaksanakan oleh FKUB Kabupaten Tasikmalaya adalah mengadakan pengamanan Natal di Gereja-gereja yang ada di wilayah Kabupaten Tasikmalaya. Latar

\footnotetext{
37 Wahyu Hidayat, Wawancara, Cikawungading 26 Oktober 2016.

${ }^{38}$ Data Monografi Desa Cikawungading 2016.

39 Tugas Forum Kerukunan Antar Umat Beragama (FKUB), adalah: a) melakukan dialog dengan pemuka agama dan tokoh masyarakat; b) menampung aspirasi ormas keagamaan dan aspirasi masyarakat; c) menyalurkan aspirasi ormas keagamaan dan masyarakat dalam bentuk rekomendasi sebagai bahan kebijakan Bupati Tasikmalaya; d) melakukan sosialisasi peraturan perundang-undangan dan kebijakan di bidang keagamaan yang berkaitan dengan kerukunan umat beragama dan pemberdayaan masyarakat; dan e) memberikan rekomendasi tertulis atas permohonan pendirian rumah ibadat. Lihat, Wawan Hernawan dan Deni Miharja, Pembinaan Masyarakat Mu'alaf Protestan di Kampung Kalaksanan Desa Cikanungading Kecamatan Cipatujah Kabupaten Tasikmalaya (Bandung: LP2M UIN SGD Bandung, 2016), 45.
}

${ }^{40}$ Kegiatan lokakarya ini dilaksanakan di Aula Hotel Padjajaran, Jalan Djuanda, Kota Tasikmalaya, Sabtu (12/12/2015). 
belakang kegiatan tersebut didasari oleh menguatnya paham radikal dan sikap intoleran antar umat beragama di Kabupaten itu. Terdapat kekhawatiran bagi Forum Kerukunan Umat Beragama (FKUB) Kabupaten Tasikmalaya, mengingat pengalaman keberagamaan Kabupaten tersebut. Untuk mengantisipasi potensi teror dan kekerasan menjelang Hari Raya Natal 2015, FKUB Kabupaten Tasikmalaya dapat berpartisipasi dalam pengamanan Gereja.

Menurut Ketua Bagian Pengembangan Kerukunan Umat Beragama FKUB Kabupaten Tasikmalaya, Utawi Jaya Kusumah ${ }^{41}$ disebutkan, bahwa personel pengamanan Gereja direkrut FKUB dari kalangan pemuda. Para pemuda yang terlibat, ialah anggota Satgas Aktivitas Nasional Hidup Rukun (GNHR) Kabupaten Tasikmalaya, yang sudah dideklarasikan. Utawi Jaya menyebutkan lebih lanjut, mereka merupakan pemuda yang berhimpun dalam sayap organisasi kepemudaan ormasormas Islam yang ada di Kabupaten Tasikmalaya. ${ }^{42}$

Selain itu, para pemuda juga berasal dari organisasi kepemudaan yang bergabung dalam Komite Nasional Pemuda Indonesia (KNPI) Kabupaten Tasikmalaya dan organisasi Karang Taruna di wilayah Kabupaten Tasikmalaya. "Kita miliki satgas, masing-masing lima orang di 39 kecamatan, dan mereka semua disebar ke Gereja-gereja yang ada di wilayah Kabupaten Tasikmalaya. ${ }^{43}$ Utawi Jaya memaparkan, di Kabupaten Tasikmalaya, ada tiga gereja yang dapat dijaga. Dua gereja Protestan, sementara satu lagi gereja Katolik. Hampir 200-an pemuda Satgas Aktivitas Nasional Hidup Rukun (GNHR), menurut Utawi Jaya, dapat dibagi untuk pengamanan tersebut. ${ }^{44}$ Dalam kegiatan tersebut ada koordinasi dengan Badan Musyawarah Antar-Gereja (Bamag). Menurutnya, pihak Gereja menyambut baik inisiatif partisipasi pengamanan Natal dan siap menopang keperluan teknis di arena lapang. Tidak cuma sekadar piranti pengamanan Natal. Satgas ini pun

\footnotetext{
${ }^{41}$ Utawi Jaya Kusumah, Wawancara, Cikawungading 26 Oktober 2016.

42 Ibid.

43 Ibid.

${ }^{44}$ Ibid.
} 
dibentuk sebagai upaya menangkal paham radikal dan sikap intoleran. Mereka, menurut Utawi Jaya, bekerja di desa dan kecamatan masingmasing untuk menjadi agen-agen kerukunan sosial melalui pendekatan humanis. $^{45}$

Ketiga, kegiatan lain yang biasa dilakukan FKUB Kabupaten Tasikmalaya adalah melakukan santunan kepada masyarakat mualaf yang berada di Kampung Kalaksanan. Di kampung tersebut, sebagaimana telah disebutkan sebelumnya, merupakan tempat paling subur terjadi konversi agama. Untuk itu, butuh perhatian dari semua pihak yang tidak hanya membina akidah mereka, tetapi pemahaman tentang toleransi, kebersamaan, dan keberagamaan, baik intern, antar, dan antara umat beragama dengan pemerintah. Hala lain yang perlu mendapat perhatian adalah perihal pangan, sandang, papan, dan keterampilan. Karena itu, FKUB Kabupaten Tasikmalaya menggandeng berbagai pihak, termasuk perguruan tinggi UIN Sunan Gunung Djati Bandung, khususnya Prodi SAA Fakultas Ushuluddin.

\section{Penutup}

Mengakhiri kajian ini, paling tidak, terdapat beberapa hal dari teori gerakan sosial Quintan yang memainkan peran sangat penting dalam menentukan keberhasilan aksi-aksi kolektif di masyarakat. Pertama, secara struktur kesempatan politik, Desa Cikawungading Kecamatan Cipatujah sama dengan wilayah lainnya di Kabupaten Tasikmalaya, yaitu termasuk wilayah yang rawan konflik baik vertikal maupun horizontal. Hal tersebut, karena secara genealogis pernah menjadi pusat perlawanan DI/TII yang dipimpin oleh S.M. Kartosuwiryo, sehingga sisa-sisa pengaruh dari ide pergerakan tersebut masih sangat kuat pada sejumlah kaum Muslim di wilayah itu. Hal lain, kaum Muslim di Cikawungading saat itu, seperti halnya daerah lainnya di Kabupaten Tasikmalaya termasuk yang ingin menguatkan identitas daerahnya berdasarkan aspirasi terkuat dari masyarakat, yaitu pemberlakuan shari'at Islam. Masalahnya, ketika penerapan shariat Islam ditafsirkan sebagai penghilangan pluralitas

45 Ibid. 
dalam kehidupan masyarakat, terutama perbedaan agama. Pada tingkat bawah pemikiran yang berkembang adalah upaya penerapan shari'at Islam, berarti tidak ada simbol-simbol agama lain, seperti Gereja dan paham-paham lainnya di luar Islam. Pandangan seperti itu yang kemudian menjadi potensi konflik antar umat beragama di sana.

Kedua, salah satu dimensi yang tidak dapat diabaikan dari proses mobilisasi gerakan sosial-keagamaan Quintan adalah resonansi bingkai (frame resonance). Konflik perseteruan di Cikawungading berjalan melalui sebuah proses yang tidak berdiri sendiri. Dimulai dengan penangkapan orang Islam yang dianggap melakukan illegal logging di satu pihak dan dibiarkannya orang Kristen dalam melakukan hal yang sama, telah memunculkan persepsi di kalangan umat Islam tentang terjadinya diskriminasi. Kasus tersebut beriringan waktunya dengan berkembangnya aspirasi penerapan shari'at Islam yang ditambah dengan kegiatan dan perilaku orang-orang Kristen sebelumnya, yang diduga telah melakukan misionnarism (Kristenisasi) di daerah itu, sehingga melahirkan sentimen keagamaan yang sangat tinggi. Karena itu, meskipun sudah dilakukan beberapa upaya dialog, peristiwa 17 September 2001 tidak dapat terelakkan.

Ketiga, dalam setiap masyarakat yang memiliki latar belakang berbeda (suku, ras, dan agama), dipandang rentan terdapat benih-benih konflik antar kelompok atau individu. Benih-benih konflik itu mulai dari skala kecil, hingga besar. Bahkan dapat menjadi konflik terbuka, ketika tidak dilakukan upaya untuk mengendalikannya. Meskipun demikian, hari ini —di Desa Cikawungading Kecamatan Cipatujah yang sebelumnya pernah terjadi konflik terbuka - telah hidup rukun kembali satu dengan lainnya. Mereka sudah terbiasa saling bahu-membahu dan saling pengertian dalam ibadah menurut keyakinan masing-masing. Mereka tumbuh dalam perbedaan. Mereka rukun dan toleran. Tentu kondisi kehidupan keberagamaan seperti tersebut yang harus dibangun dan ditumbuhkan di masyarakat. Kehadiran instansi pemerintah, lembagalembaga di bawah Kementerian Agama, maupun Perguruan Tinggi sangat diharapkan untuk berada di tengah-tengah mereka. Bentuk 
kehadiran yang diharapkan, terutama dalam momentum kegiatan Peringatan Hari Besar Keagamaan dan kegiatan peningkatan sumber daya masyarakat melalui pelatihan.

\section{Daftar Rujukan}

Atan, Hendrianto. "Kita Butuh Agama yang Peka Tuntutan Zaman", dalam Nurcholis Madjid et al., Islam Universal, Yogyakarta: Pustaka Pelajar, 2007.

Berger, Peter L. The Sacred Canopy, terjemahan Hartono, Jakarta: LP3ES, 1990.

Dakir. "Pengelolaan Budaya Inklusif Berbasis Nilai Belom Bahadat pada Huma Betang dan Transformasi Sosial Masyarakat Dayak Kalimantan Tengah”. Jurnal Religio, Vol. 7, No 2, 2017.

Data Monografi Desa Cikawungading 2015.

Eliade, Mircea. "Realitas yang Sakral", dalam Daniel L. Pals, Seven Theories of Religion, terjemahan Ali Noer Zaman, disunting Ruslani, Yogyakarta: Qalam, 2001.

Falah, Miftahul. Sejarah Kota Tasikmalaya 1820-1942, Bandung: Uga Tatar Sunda dan YMSI Cabang Jawa Barat, 2010.

Geertz, Clifford. "Agama sebagai Sistem Budaya”, dalam Daniel L. Pals, Seven Theories of Religion, terjemahan Ali Noer Zaman, disunting Ruslani, Yogyakarta: Qalam, 2001.

Hasan, Noorhaidi. "Book Review: Islam Politik, Teori Gerakan Sosial, dan Pencarian Model Pengkajian Islam Baru Lintas-Disiplin", AlJami'ah Journal of Islamic Studies, Vol. 44, No. 1, 2006.

Hernawan, Wawan. Seabad Persatuan Ummat Islam, Bandung: PUI dan YMSI Cabang Jawa Barat, 2014.

Hernawan, Wawan dan Miharja, Deni. Pembinaan Masyarakat Mu'alaf Protestan di Kampung Kalaksanan Desa Cikawnngading Kecamatan 
Cipatujah Kabupaten Tasikmalaya. Bandung: LP2M UIN SGD Bandung, 2016.

Insttute, 2015. Komnas HAM, Laporan Tahunan Kebebasan Beragama dan Berkeyakinan 2016, Jakarta: Komnas HAM, 2016.

Ismail, Nawari dan Muhaimin. Konflik Umat Beragama dan Budaya Lokal, Bandung: Lubuk Agung, 2011.

Iwamony, Rachel \& Relmasira, Tri Astuti. "Rekonsiliasi sebagai Proses Bersama Menyembuhkan Luka Sejarah Islam-Kristen di Kota Ambon", Jurnal Religio, Vol. 7, No 2, 2017.

Kahmad, Dadang. "Kajian tentang Pengambilan Keputusan untuk menjadi Pengikut Tarekat Qadiriyah Naqsabandiyah; Studi Kasus di Kecamatan Ujungberung Bandung", Tesis S 2 tidak dipublikasikan, Bandung: Universitas Padjadjaran, 1993.

Khalikin, Ahsanul dan Fathuri. Toleransi Beragama di Daerah Rawan Konflik, Jakarta: Puslitbang Kehidupan Keagamaan Badan Litbang dan Diklat Kemenag RI, 2016.

Padmadinata, Tjetje H. "Panggung Karakter Elite Sunda", dalam HU Pikiran Rakyat, 5 April 1997.

Pritchard, E.E. Evans. "Construct of Heart' Masyarakat", dalam Daniel L. Pals, Seven Theories of Religion, Alih Bahasa Ali Noer Zaman, Peny Ruslani, Yogyakarta: Qalam, 2001.

Profil Desa Cikawungading Kecamatan Cipatujah Kabupaten Tasikmalaya Tahun 2016.

Setara Institute. Report Summary Tolerant City Index 2015, Jakarta: Setara Institute, 2015.

Salehudin, Ahmad \& Ichwan, Moch Nur. "Revitalisasi Identitas Diri Komunitas Masjid Saka Tunggal Banyumas, Masjid Raya Al Fatah Ambon, dan Masjid Agung Jami' Singaraja Bali dalam Perubahan Budaya Global” Jurnal Religio, Vol. 7, No 2, 2017. 
The Wahid Institute. Laporan Tabunan Kemerdekaan Beragama/Berkeyakinan (KBB) di Indonesia: “Utang” Warisan Tak Kunjung Terlunasi, Jakarta: The Wahid Institute.

Wiktorowicz, Quintan. (ed.), Islamic Activism: A Social Movement Theory Approach, Indiana: Indiana University Press, 2004.

\section{Web Site:}

Komunitas Member Milis GP 2000, "Dua Gereja dan Puluhan Rumah Warga Kristen Dibakar", dalam http://www.communityzero.com/gpgpib/ diakses 05 Oktober 2018.

Upiek S. dan Y. Tomi Aryanto, "Diduga Akibat Persaingan Usaha Kerusuhan di Tasikmalaya, 36 Rumah dan 2 Gereja Hancur", dalam http://www.oocities.org/baguala67/tempo190901.-htm?20185/ diakses 07 Oktober 2016.

\section{Wawancara:}

Edeng Z.A., Wawancara, Tasikmalaya 26 Oktober 2016.

Wahyu Hidayat, Wawancara, Cikawungading 26 Oktober 2016.

Utawi Jaya Kusumah, Wawancara, Tasikmalaya 26 April 2016. 